第61回日本内科学会满演会 (1964年)

会 頭 演 説

内科学原論の必要 性*

京都大学教授 前川孫二 郎

\title{
ABOUT THE NECESSITY FOR THE PRINCIPLE OF INTERNAL MEDICINE
}

Magojiro MaeKawa, M.D.

Third Medical Clinic, Faculty of Medicine, Kyoto University

学問は進歩するにつれて分科する．対象と方法 に対するわれわれの意識がその密度を高めるから である．從つて昨今の医学が続々分科するのは何 の不思挛むな、本学会からもここ10数年のうち に殆ど20に近い專門学会が巢立つていると思う。

演者も日本偱環器学会主晏教空の一員として殆ど 40年の歳月を循環系の専攻に過した。そこには 今でも困難な幾多の問題が山積しているが， 当時は殆ど凡ての問題が五里霧中のうちにあつ た。流石に40年の歳月は，循環系における多くの 困難な問題に次第にその道を開きつつある。そし てその功續の殆ど凡ては循環系の尃闍化に負う といえよう。そしてこの結果は益々循環系の專門 化に拍車をかけようとしている。然しそれにも拘 らず心脈管の疾病による死亡桼はわが国のみなら ず一般の文明国において疾病死の第 1 位を占わて いる．高血圧症及び動㟲硬化症に基づくいわゆる 眇心腎の疾病死である。そしてそこでは循環杀の 専門化によつて問題が解決の方向に向うよりはむ しろ混乱の状態，大げさにいえば複雑怪奇の状態 に導かれつつあるといえる，何故か，乏の理由は 色々あるうが，その主なるものは循環系尃閒とい う狭い谷間で却つてその眼界がさえぎられている

*1964年 5 月9日，京都本京都会館にて誥演された。
ためではないかと思う。高血圧症や動脈硬化症は 単に循環系の問題ではなく, 広く一般の臨床, 否 一般の医学の問題だからである。勿論医学におけ る專門家の第一の条件は立派な内科医，むしろ立 派な医者一般である。このことは周知で，大抵の 尃門書に説かれている。しかしその意味が果して 正当に，そして事箺に㧍いて理解されているであ ろうか。その条件とは主として循環系疾患を他系 統障害との連蓀にちいて理解する能力のことであ る. 垖ち循環系疾㭧を追究し解明する際は勿論, これを診断し，治療する際にも，循環系専門の立 場だけでは全く不完全であり，且つ危険をさえ伴 ないうることがあるということである。これは決 して誇張ではない，そしてこのことは単に循環系 のみの問題ではなく、神経系も，内分泌系も，呼 吸系や更に消化系，代謝柔，関節や運動系の尃門 においても，等しくそうであるといえよう。のみ ならす外科方面においても事情は全く異ならない と思う.以下私の淔接経験した幾つかの重要な例 を述心，今㷋の医学，特に専門化する踀床医学の 対策について一言したいと思う。

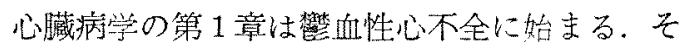
れでこの講演の第 1 章も不応性心不全を中心に話 を進わよう。

心不全の治療は新しい利尿剤, 特にthiazides绪 
とaldosterone拮抗剤との登場によつて比較的容 易になつた。しかしその半面不応性心不全を導 く危険が增大しつつある。そしてこの最も有力な 原因の一つとして心不全の際の禁血畈による低ア ルブミン血症と，それを知らずして強力且つ長期 に互るナトリウム利尿を講ずる結果が人工的の二 次性低アルト゚ステロン症を若起することが考えら れる. 又この故に不応性心不全には低ナトりウム 血症と 1 日尿中排出のアルト゚ステロンの低下が見 られるのであ万う1)。そしてこの事実は今日の主 題にとつても示唆するところが多いと思うので少

しく詳述したいと思う。

先す心不全と䀒臟障害の関係について述べる。 心不全の際に䀒藏が意外に重大な障售をうけて いる事実は既に病理学者初から 指摘されている。 しかし周知のように心不全に際して旰の障害が前 景に出ることはむしろ稀である。しかし今心不 全の度をNew York Heart Associationの分類 $\left(I^{\circ}, \mathbb{I}^{\circ}\right.$ ， $\mathbb{I I}^{\circ}$ 及び $\left.\mathbb{V}^{\circ}\right)$ に従つて定め。これと 諸種の旰機能検查成績との関係をみると，何れの 䀒機も不全の度合が進むにつれ，これと略々平行 して増悪している。

slide 1 (略)：黄揎指数 $\left(I^{\circ}: 5.3, I^{\circ}: 6.7\right.$, $\left.\mathbb{I I}^{\circ}: 8.2, \mathrm{IV}^{\circ}: 9.7\right)$

slide 2 (略)： 総ビリルビン $\left(\mathrm{I}^{\circ}: 1.4, \mathbb{I}^{\circ}\right.$ : 1.04, $\left.\mathbb{L}^{\circ}: 1.4, \mathbb{V}^{\circ}: 2.1\right)$

slide 3(略): 直接ビリルビン $\left(\mathrm{I}^{\circ}: \mathbf{0} 0.35\right.$, $\left.\mathbb{I}^{\circ}: 0.53, \mathbb{I}^{\circ}: 0.67, \mathbb{V}^{\circ}: 0.72\right)$

slide 4 (略): $\operatorname{BSP}\left(I^{\circ}: 4.8, \mathbb{I}^{\circ}: 9\right.$, $I^{\circ}: 13.6$, IV $: 20.0$ )

又血清蛋白については，総蛋白，アルブミン， $\mathrm{A} / \mathrm{G}\left(\mathrm{I}^{\circ}: 1.11, \mathbb{I}^{\circ}: 0.95, \mathbb{I}^{\circ}: 0.85, \mathbb{V}^{\circ}:\right.$ 0.82), 特にアルプミンは心不全の度合に比例して 減少を示している。 関係はない。師ち，

slide $5($ 略 $):$ 総蛋白 $\left(\mathrm{I}^{\circ}: 6.76, \mathrm{II}^{\circ}: 6.76\right.$, $\left.\mathbb{I}^{\circ}: 6.70, \mathrm{~V}^{\circ}: 6.47\right)$

slide 6(略): アルブミン $\left(\mathrm{I}^{\circ}: 3.25, \mathrm{II}^{\circ}\right.$ : 3.22, $\left.\mathbb{I}^{\circ}: 3.05, \mathbb{V}^{\circ}: 2.9\right)$

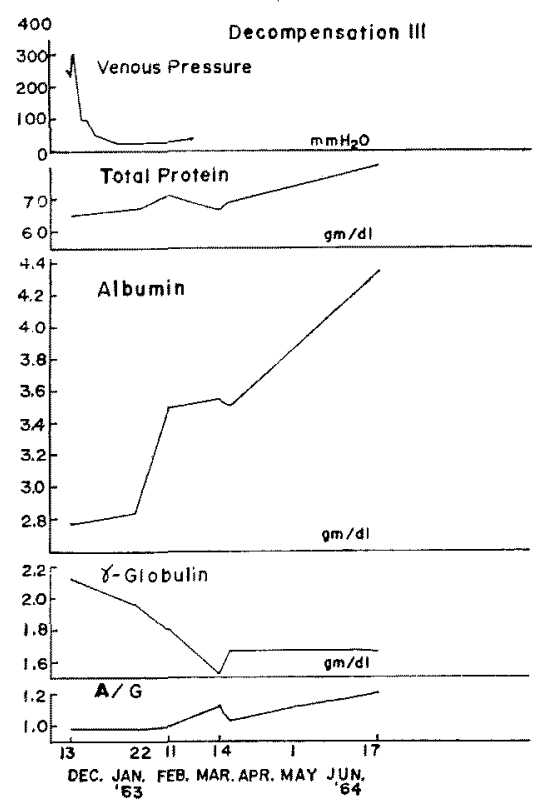

图 1. Change in Serum Protein. T.Y. $60 \mathrm{y} \cdot \mathrm{m}$. Coronary Heart Disease

そこで (slide 7 (略)) 静脈王の上昇は心不全 の度合と比例することを考えると，心不全の浮腫 には低アルブミン血症が当初から幾分の関係を持 ち，重症になるに彷つて次第に無視出来ない程の 重要な役目を占めていることがわかると思う。か かる際の浮腫にシギタリスが作用しないのは自明 であろう。

従つてこのような際には強心, 利尿の外に蛋白 を補給することが本質的な心不全の療法の一つと なる. 次の症例はこの間の事情を示す。

症例 1 (図 1).T.Y., 60才，男，冠状心疾患， 不全 $V$ 度, 大院当初（Dec.13，'62），静脈圧 300前 後, 血清蛋白, 総 6.5 ，アルブミン 2.75 , ジギタ リス飽和で静脈生は半力月で正常化，しかし血清 蛋白はskimmed milk（30G1日）投与によつて 約半年後に漸く正常に加えつた。をして現在その 代筫性頗る安定してジキタリスを必要としない，

このような例は外にもるる。印方本例の如き冠 状心疾患はかかる療法の下で一定期間を過ぎる

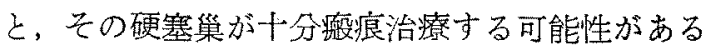
からである，然しそうでない場合，師ち心不全の 原因が不明か，不治か，或いは見落されている場 
合はその心不全注勿論不安定で，凡ゆる努力にも 拘らず次第に不応性心不全に導かれて行く，従つ て第 2 として心不全と原因療法との関係について 述べる，師ち，不安定性心不全の例である。

症例 2 ： M.K., 21才, 女, 急性リウマチ熱, 連合性弁疾患，心不全IV度：この例 はA SO值 $833 \mathrm{~T} . \mathrm{U} ., \mathrm{CRP}+4$, 赤沈中等価 $65 \mathrm{~mm}$, 咽頭培㙋 でß溶連菌十，血液及で骨髄培養共に陰性。この

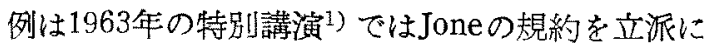
満足する急性りウマチ熱としてその心不全例に対 して、シギタリス， steroid及び抗性物筫の3者 併用療法を以てしなければ完全な洽療効果が得ら れない実例として供示した。 ところが (slide 10 略）その後経過が安定せず1963年の 5 月頃から 発熱し時々 $38^{\circ} \mathrm{C}$ をえ元，赤沈，C R P 值が上开 し，その都度心不全の徵をあらわした。そしてそ の都度上記のリウマチ性と心不全とに対する療法 を調節し, 又旰繶血のための血清蛋白，特にアル ブミンの低下（3G\%以下）に対してskimmed milk（30G1日）療法を行なつたが，経過は依然 として安定するに到らなかつた。そして一旦下降 していたASO値も再び上昇し(slide 11 略)， 関節痛があらわれ12月には脾腫をみるに到つた。 そこで血液の培盖をするも依然として陰性であつ た、しかしその経過，特に脾畽を見るに到つたを ころから亞急性心内膜炎を考え， steroidなかん ずくペニシリンを增量した。をの結果は脾腫去 り，ASO值も正常化し，全身状態著しく改善し た。多分稀有な溶連菌性亞急性心内膜炎已考えら れる。抗生物質を廃し今一度血液培埕を行なつて 実証したいと考えている。

本例は心不全の治療に当つて，仮えその治療が 適格であつても安定した代償がえられない時は， 原因䛦断の不備を考えね壮ならないことを教え る，fibrin を浸透して原因菌に作用するためには 血中のpenicilline濃度が十分高くなければ疗らな いからである。

しかし原因診断が適格であつても，現代医学で は尚手の施しようもない場合必ある。かかる祭は

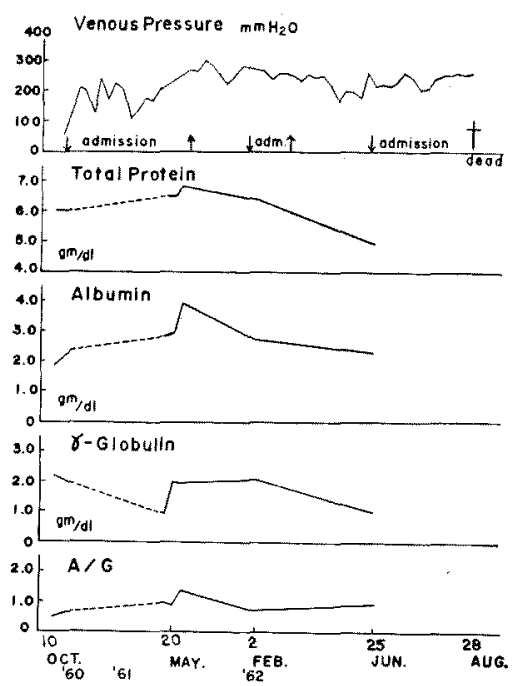

2. Change in Serum Protein. M.Y. 20 y.m. Marfan's Syndrome Decompensation IV.

必然的に不応性心不全が導かれるが，その際生体 はわれわれの心不全に対する治療手段に対して如 何なる反応を示すだろうか，次の2例を代表とし て考えてみよう。

症例 3（図 2）：M.Y., 26〜28才, 男, Marfan 症候群, 大動脈一左室一右室短絡症侯群, 亞急性 細菌性心内膜炎，心不全 $\mathrm{V}^{\circ}$.

この患者は最初大動脈不全症と亞急性細菌性心 内膜炎として昭和 35 年 10 月入院してきた。その際 蜘蛛指，脊杜彎曲，鳩胸がある所からMarfan症 候群々診断， 2 年後の 37 年 6 月入院中急死 : 剖検 によつて大動脈，なかんずく肺動脈にcystic medionecrosisがあり，Marfanなることが確認され た例である. 又亞急性細菌性心内膜炎は臨床的に は第 1 回目の人院時に治療されたが，組織的には 各臟器に小結節性肉牙腫の形で残留していた。大 動脈一左室一右室短絡症候群は大動腿弁の穿孔が 上記室中隔欠損孔を通じて行なわれていたもので あつた。このような状態では所詮安定した代償は えられず，第 1 回入院時忹亞急性心内膜炎の治療 で可成り回復し，静脈压 200 前後から 100 近く に，血清蛋白，特にal.8 $2 \mathrm{G} \%$ から $4 \mathrm{G} \%$ ま゙， $\gamma$-gl.は $2 \mathrm{G} \%$ 以上から $1.0 \%$ 以下に落ちた。し 
加し退院後の不摄生もあり，状態は次第に覀化 し，静服圧も再び上暑し，300〜200附近に稳留 L，血清総蛋白は低下し 総蛋白 $5 \mathrm{G} \%$, al. $2 \mathrm{G}$ $\%$ に至る。そして 37 年 2 月 2 度目の入院後(slide 13 (略))軽度の減塩, 抗生物質, シギタリ又等の 基礎治療は従来通り犬゙が，これに2月13日〜3月 6 日の経過に芫る如く, thiazides, spironolactone

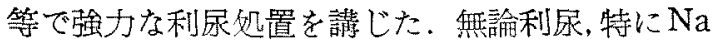
利尿は著明につき，体重も急激に減少し，一般忋 態は改善した。しかるに 1 日尿中排泄のaldosterone, 17-OHCS攻びcatecolamine (C.A.) は顯著 な上昇を示す（それぞれ最大 $74.2 \mu \mathrm{g} / \mathrm{dl}, 11.3$ $\mathrm{mg} / \mathrm{dl} ， 300 \mu \mathrm{g} / \mathrm{dl}) ，$ そしてこれらの亲化山静脈 王と血清Naの極く僅かな減少と対応したに過ぎ ない。

そこで 5 日間の間隔をおいてspironolactoneを $600 \mathrm{mg} / 1$ 日に増量し，再び同様の利尿処置を講 じ，著明な利尿を導き，静脈瓜を100近くまで降 下せしめ得た。しかしこの際既に一時的ではある が血清Naが $130 \mathrm{mEg} / \mathrm{l}$ 近くまで下降している

(slide $14(\mathrm{MY}-2)$ ，図 $3 \mathrm{~A})$. しかし再び静脈生 300近く上景，1日尿中aldosterone，C.A.沬上 舅，そこで 1 日1 Gの減塩を行ない7月14日より 再びspironolactone 1 日 600mgで利尿を行なう。

体重は著しく減少したが，静脈圧はそれはぼ下降 せず200近くに止まつた。

slide 15, 図3B： そこでspironolactoneを廃 止し経過を見たが，血清Naは回復するも体重再 び上昇し,肺活量も減少の傾问を示すので, 8 月13 日にtriamterene（200mg）利尿郕として投与し た、Na利尿は軽度あるも尿量增加せず，1日永 中aldosterone, C.A.顯著に増加, 然L17-OHCS の増量はなかつた，そして血清Naは著明に下 降，低Na血症を呈して来な、静脈王はむしろ上 具の傾问。そこでtriamtereneを再び投与するも 效果なく，1日层中のaldosterone，17-OHCSを 測定するに最早增量を見なかつた。低 $\mathrm{Na}$ 血症

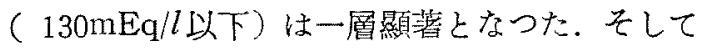
不幸な転帰をみたのである。

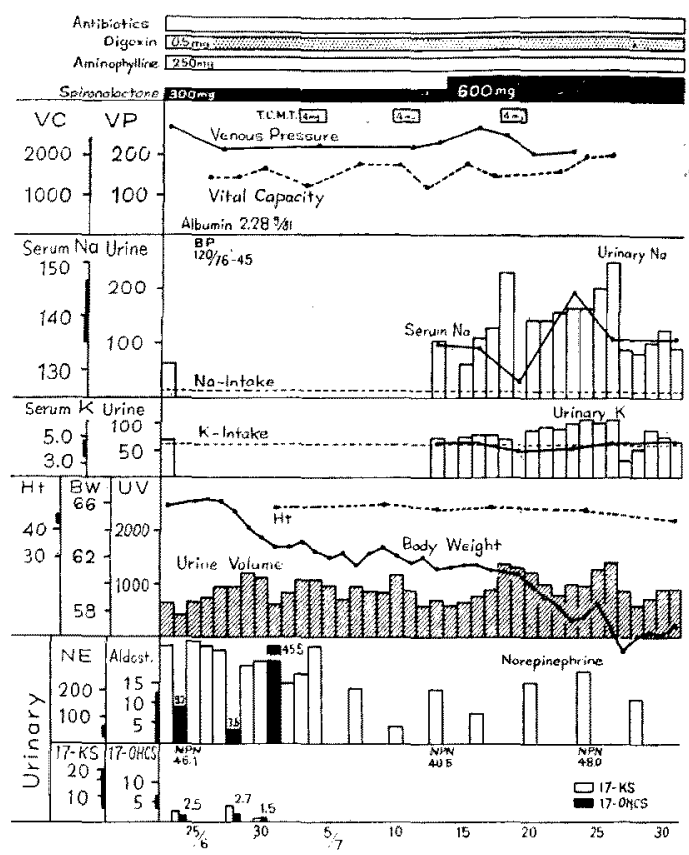

(X. M.Y. (2) Decompensation IV 28-y.m. Marfan's Syndrome, Endocarditis, Aor-LV. RV Syndrome.

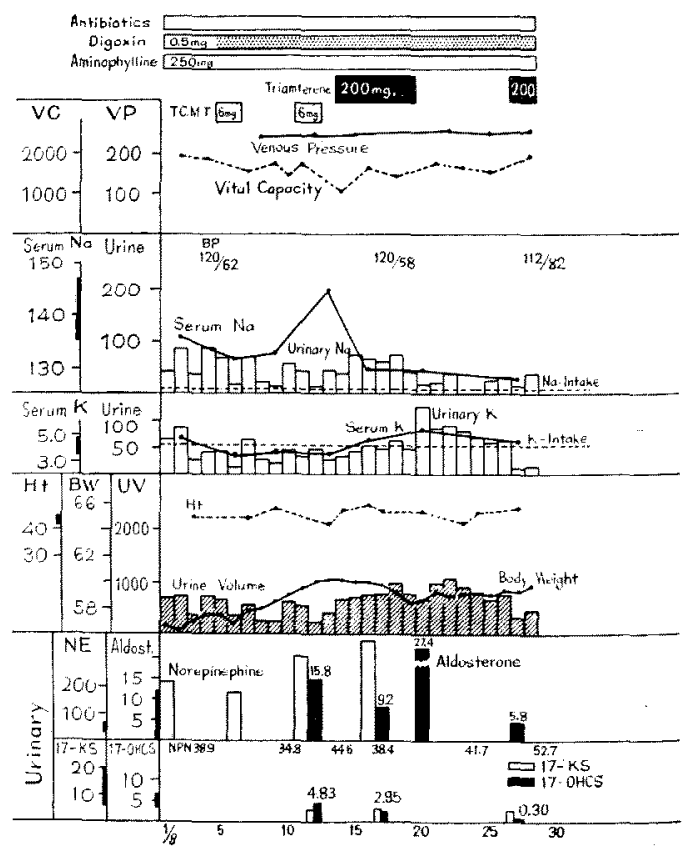

ब 3 B. M.Y. ( 3 ) Decompensation IV 28y.m. Marfan's Syndrome, Endocarditis, Aor-LV-RV Syndrome. 
師ち本症は原因治療が可能でない埸合，敢てそ つ心不全を強力な利尿によつて短正しようとする 上，当初その生体は神経内分泌調節紊が健全であ る内は，その徐制利尿に対して適応反応で応じ，

事なきをうるが，しかしこの系が次第に疲䔩する に及方々，最早強制利尿に対して順応しえなくな $り$ ，単純な因果律の結果たる低Na血症状を呈し て来る、そこに不応性心不全の原因があることを 教えていると思う。

症例 4(slide 16, 略)：T.I., 34才, 男, 変 形Fallot四徴症 (Triology), 心不全 $\mathbb{V}^{\circ}$.

この例を手術不可能の状態で, 当初(昭和37年12 月加翌 1 月に加けて) 前例々略々同様の強心, 利杘の処置を講じ，殆ど同様の効果と反応とを見 ている. 特にC.A. とaldosteroneの增量に対し，血 清Naの軽度隇少が㞶応する。しかし次のslide 17 を御嗐原いたい。

slide 17(略)：これの最初の部分は前の後の部 分の重複であるが，その後( 1 月15日以後) 血清Na は次第に回復を示すが，体重が再び增加し始め， 静脈压も200附近を持続する。そこで1月25日再 び spironolactone 400mg 1 日で利尿を計つた。し かしこの度は利尿全くつかず，静脈任や体重は却 つて上昇し，血清Na涛激に下降する，そして 1 日尿中 のaldosterone及び17-OHCSは低値に止 まつた。そして虫者は死亡したのである。

症例 5 (slide 18・19, 略)：S.K., 24才, 男, Valsalva洞右室破裂，心不全 $\mathbb{I I}^{\circ}$.

この患者は臨床症状，特異な胸痛発作，持繶性 心㮒音，右音不全等によつてValsalva洞破裂を 診断しえた例で，手術可能にまで代償を得ようと して強心，利尿治療を行なつたものである，そし てこの患者は前記 2 患者の示した強制長期利尿 が 1 日尿中aldosterone (34) やC.A. 又17-OHCS (18.6)を次第に顕著に上开せしめる事実方普遍的 であるということを教える。即ちspironolactone とthiazideによる利尿は初回( slide 18,略)よりは 第 2 回目(slide 19, 略)が强く,血清 $\mathrm{Na}$ 低下も同様 である，そしてたとえ体重や静脈圧を一旦減少せ
しめても，强制利尿処置を廃止寸れば，又元一㞔 ることを教える。本㭧者は東京女子医大の楖原教 授によつて手術され，現在僅かの䀒機能障害を残 すのみで殆ど完全に健康を回復している。

以上のょうに心不全の完全な療法法ての原因に 向つてもなされなければならない。さてそれれな らば心不全の瘵法は原因にのみ向ければよいかと いうとそれは決してそうではない，次の例はそれ を示す。

症例 6(slide 20, 略)：T.S., 60才, 男, 高血圧 症性心不全, $\mathbb{I I}^{\circ}$, 心不全には常にC.A.が堌量し ており,guanethidine (3) は節後交感神経僬断剩 であり，C.A.の分泌を卯制するのみならず血場 压降下剂でもある。良つて本剂は本患者にとつて その心不全の原风療法となりうると考えられる。

ところがguanethidine壮本患者の心不全を毫も 改善しない，そこで利尿剂でもあり，降圧剂でも あるthiazideを加えた。それでも效果瑟しから ず。そこでシギタリスを処方卞るに容易に心不全 は回復した。やはり心不全にはまずシギタリス を、そして原因療法はこの療法を基盤にした上で 行なわるべきですること，及び心不全の際のC.A. の增量注不全時の順応反応であり，病理的という よりは生理的と考えるべきことを教える。

以上で不応性心不全が何故偱環系専門家にとつ て，不芯性であるかの所以が理解されると思う。 症例 2 が原因裺法不完全のために 3 年に亘る心不 全を繰返しながら，不応性に陷らずしてすまされ たのは高蛋白食による旰葴此護と血清アルブミン の高度低下を防ぎ得たからであろう。われれの ところではこの蛋白補給の療法を心不全に適㲿し て以来，心不全の療法の成功率が良いことを経験 している，第 1 例はその適例である，その上心不 全に対する利㽷処置は，単なる利尿のみに心を窟 われてはならない，それによつて体滩の容積，圧 力, 組成, 酸塩基平衡等についてのhomeostasis が 攪乱され，そこに激しい動力学的の適応現象が余 儀なくされていることを知らなけれ将ならない。 師亏内部環境調節系に重大なstressを与えてる 
のである，心不全はそれ自身慢性であり，加つ何 れの組織も多少ともに酸素欠乏の状態におかれて いる。このことを考えると，强力なそして長期に 互る利尿が次第に内部環境の調節采を疲幣に導 き，遂に不䧹性心不全を結果することは当然のこ とといわなければならない。

第 2 章は本態性高血圧症を選将う，高血压症が 循環系を冕脱することは周知である。師ちこれを 重要な症状に持つ疾患は仲々に多い.特に脈管系， 神経一内分泌系及び腎系疾患である。しかし又食塩 か゚高血圧症に重要な関係を有することは，実験的 のみならず高血圧症の治療の上からも明らかであ る。そこで今日本態性高血圧症の真の病因は明ら かではないが,多くの学者の一致する意見は, 本態 性高血圧症は単一の因子ではなくて，多数の因子 の相互作用によると考える，師ちPageのmosaic theory4)が有力と考えられている。 しかし問題の 諸因子は，食塩をも含めて，传にみてきたように， 心不全にも関係している。だかといつて心不全 の病因を多因子性mosaic或いはfacetsだと考えう るであろうか，そこでわれわれが管て (1961) 行 なつた高血圧症5についての臨床実験を引用する ことを許して頂き度い。

slide 22(略)： 実験は 本態性高血圧症の3 名 （内1名は若年者）の外に，原因の明らかな内分泌 性のCushing症候群，活動性acromegaly，腎性の 筲盖腎炎の各 1 名,都合 6 名をえらび, これ等の高 血圧患者一定の降圧処置の条件下に扮，その 際の神経内分泌系の区応を 1 日尿中排泄 のC.A. aldosterone, 17-OHCS の測定によつて調べた。 高血圧の程度はSmithwick法で全域に宣る。

一定の降王条件としては，高血在症の基礎療法 の一つと考元られる笽重減塩食 $[1 \mathrm{G}(17 \mathrm{mEq} /$ 日) 及びこれに続いて thiazides 降圧戍の追加を以 てした。この条件は既述の心不全時のそれに類似 で，雨者に招ける反応形式の此較に便利である j.

slide 23(略)：入院時の娭査成續ではC.A.は 第 2 例の本態性高血圧症でV.M.A. (3-methoxy- 4-hydroxymandelic acid) 方僅かに高值以外概 权正常であつた。 aldosteroneも第 3 例の若年者 高血压症で高值をみた以外は凡て正常，17-OHCS は第 5 例の acromegaly，第 6 例のCushing は当 然としても，第 3 例の若年者高血王症々第 4 例の 腎盖腎炎ともに高值を示した。

K摄取量は実駼の全期を通じて $60 \mathrm{mEq} /$ 日とし， 2 週間の control期をとり，その間 1 日食塩10G ( $170 \mathrm{mEq})$ とした.

slide 24(略)：さてこれらの患者を低程下 $(17 \mathrm{~m}$ $\mathrm{Eq} /$ 日）におくと，血圧は 6 名中 3 名が降下を示 した。降下を示さなかつたのは若年性高血王症の みであつた。

C.A.はnorepinephrine (N.E.) が最 文特街的 で, 低塩で若年性高血圧症を除き凡て著明に増量 した。若年性もthiazideを加えると增量した。

Aldosterone: Cushing症候群を除き隇塩で凡 て増量した. Cushingでは17-OHCS值が高く、こ れもある程度の鉿筫corticoidであるためかも知れ ない。

以上の成績はC.A.を除いては周知の通りであ る.そしてC.A.の示す反応は大体次の 3 型に区別 された。

slide 25, 四 4 ： I；低塩食で血圧が下降し C.A.の排浙量方增加する場合， thiazideを加えて 女不変（第 1 例, 第 2 例の本態性と,第 6 例のCushing). II；低塩食で血压は下降しないが，C.A.の 排泄量は增加する。しかしthiazideを加えると血 圧の降下がおこり，第I型に移行（第 4 例の腎㙉 腎炎，第 5 例のacromegaly)。 III；低塩食では血 圧下降もC.A.の增加もおこらないが， thiazideを 加えると血压は下降しないが，C.A.は增加してく

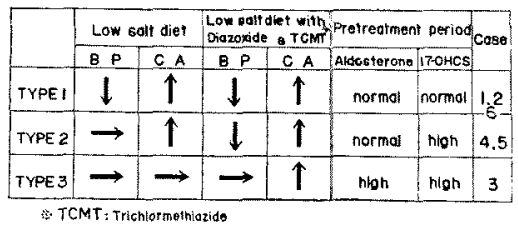

図 4. Three Reaction Types of Hypertensives to Low Salt Diet. 
る、的ち第 II 型に移行する（第 3 例の若年性高血 圧症).

次に実例の 1 ～2 示そう。

slide 26 (略)

I 型 case 1

slide 27 (略)

II 型 case 5

slide 28 (略)

III 型 case 3

長期における減塩やthiazidesは共に細胞，特 に脈管細胞の内外における電解質，特にNaイオ ンの分布に影響して，眽管のC.A.に対する感受 性を低下せしめ，血王降下性に作用し，耐者の併 用は加算的の作用を示すといわれる6) 10)。こころ でわれわれのこの実験で示された事実は減塩，及 び減塩とthiazidesの併用は何時の場合にもC.A. を增量せしめる。しかも血圧架降下しない場合も そうである，その反応形式の移行は常に强力な 血圧降下処置に対応して， III型加ら II 型八， II 型 からI型へである。これらのことを考えると高血 圧症，少なくとも代表的な高血圧症では減塩や thiazidesによる降圧処置を講ずると, 却つてC.A. の分泌を增加しその降圧作用に対抗する如く見え る、そしてこのことはこの際の㻌質corticoidsの 反応態度を総合して考えると一層確実性を带び る. 師ち減塩に対して鎑質corticoids殊にaldosteroneがCushingを除き凡てにおいて增加したが, しかし血压降下に抵抗したI型及び更に抵抗を みせた型は共にそれぞれ部分的及び沉発的の hypercorticismを示すものである．即ちこれら患 者はこのことによつてNaイオンに対するより強 固なhomeostasisをもつことが考えられる。かく みてくると三つの型の反応形式は極めて自然且つ 合理的に理解される.

そこでこの反応を前述の心不全に於ける强制利 尿のそれと比べる，降圧と利尿との差を別にす ると，甚た酷似していることが分る。ところで心 不全の際に強制利尿 がC.A.やaldosteroneを增量 するのは心不全の原因が除去されない場合であつ た。從つてこの高血圧症の際も減塭やthiazideが C.A. paldosterone 増量するのは高血圧症の原 因がそのま〉にされているためではなかろうか。
Cushing, åcromegaly，婜需婜焱等は正にそう である，そして全く同様の反応を示す本態性高血 圷症も事情は变るまいと思われる。それ故に減塩 やthiazidesの降厈手段は，単に対症療法として C.A.やaldosterone等の増量, 邲方生体のhomeostasisの機㙉が動員されて，原因によつて設定さ れた高い血圧レベルを維持しようとする反応のあ らわれではなからうか，汃く考えると，高血压症 に対するmosaic theoryはあやしくなるのであ る、卵ち現今本態性高血圧症といわれるものも， 何等かの未知な原因が存在すると考えなければ ならないであろう。そしてその解明に不可欠の 前提は血圧值の設定機構である ${ }^{11}$ 。ここの機構は勿 論血圧の調節機構とは異なる。調節機構とは設定 された血王值を諸種の条件に対して維持しようと する作用であり，血圧設定を前提として初めて存 在しうる機構である。神経，内分泌系はかかる調 節機構に属し，血圧設定のそれではない.然らば血 生の設定機構とは何か。これは他のあらゆる生物 学的常数におけると同様全く不明である。しかし それは(slide 29，図5)この模式図にみられるよ うに，心脈管系の自律性分循環血液量を介して行 なつているのではないかと考えられる1)。このこ とは心臓ではStarlingの心臓法則として最近再確 諗されたところであり，脈管の自律性は腎、肺循環 のみならず，体循環においても，その存在が次第 に明らかにされつつある。勿論この自律性は心服 管系における筋の作用, 郎ちActo-Myosin型の ATPase-ATP系の機能と考えられる。そして本 態性高血王症とはこの血生設定機棈, 師ち心脈管

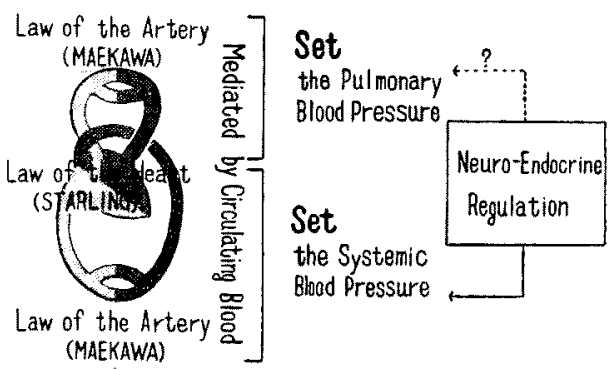

図 5. Blood Pressure "SET". 
ATPase系の陸害が最も疑わしくなるのであり， この仅説は䠶に1953年12わたくしの提出したとこ ろである。

そこで問題になることが二つある。その1： acromegaly, Cushing症候群，原発性aldosteronism, 好クローム細胞腫その他の調節樂の特殊 疾患吕，何故本質的に同質な高血圧症を結果する のであろうか，その2： 心不全と高血压症にお いて，同漛の stressは同㥞の調節系の区応を来た すに拘らずその結果は前者と後者乙で甚だしく異 なるということである。第1に刘する理由は尘体 内に於ける酶装系の平衡は動的，開放系であり， 従つて調節子の效果はこれ等の脿素器官である心 ・脈管筋の肥大, 線維化等の現象を惹起寸るとこ ろにあると考无られる。第 2 の問題は，いわゆる stress 疾患に扔计る特殊性の問題として後述す る。

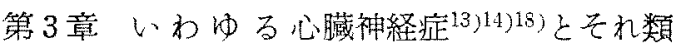
似の疾患，特に原発性即ち孤立性不整腿に就いて

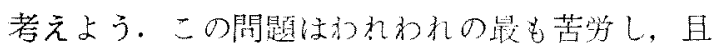
つ議論の多かつた領域であり，且つわたくしをし て壴門化一の疑問を抱加し及端緒をなしたもの

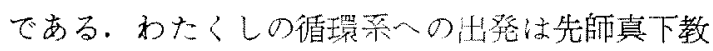
授の助手として检查方法の研究加ら始まつた。今 から 40 年前のことである. 当時のわたくしに心臓 神経症は客観的所見のない大げさな愁訴をもつ 奇妙な疾患として写つた。しかし経験妾重效るに 従つてこれらの愁訴がある一定のいろいろな patternを名方，特には同一人において或時はこ opattern, 又或時は他のpatternという風に移勤 或いはsee-sawすることさえあるのを知つた。

slide 30(略)：このslideは昭和26〜35年の間 に入院してきた神経症患者 334例の愁訴頻度の統 計で，多いものから順序にあげてある。惓怠 $(66 \%)$ ，心悸六進 $(59 \%)$, 頭痛 $(51 \%)$ ，呼吸困難 $(51 \%) ，$ 眩睴 $(50 \%)$ 等となつている。

slide 31(略)：このslideは以上の愁訴がある 一定の pattern を形成する覀奏を統計起理で示し たものでる。実倍線が有意 $\left(\chi^{2}>10\right)$ 相関，点傍 楾が有意逆相関を示す。例えば心悸艺進は賠晕， 項部緊張感，屑凝，胸部絞扼感，呼吸困難，'胸痛
と patternをなし易く,腹痛とはそうでない，逆に 腹部愁訴（心简部の疼痛又は不快感，或いは腹部

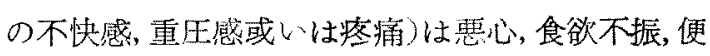
祕之一定のpatternをなし，心悸兄進，胸部絞把 感，呼吸困難とはそうでない，勿論まだその他の 小さなpatternもあるが，この二つが代表的なる ので, 前者は今日 neurocirculatory asthenia (N. C.A.: 神経循環疲学症), 後者は腹部神経症として 周知であり，又よく問題としてとりあげられる． しかしより小さなpatternや要素的な愁訴が前 景に立つこともをう珍しいことではない，即方 N.C.A.の要素である呼吸困難, 胸痛, 心悸元進 (不整脈) 等はそれぞれ孤立性（lone）に愁訴さ れ，神経性喘息 ${ }^{15}$ ，脈管運動性狹心症 ${ }^{16)}$ ，㧓立性 不整脈 $\left.{ }^{17}\right)$ 等と呼ばれているものに相等する。腹部 秆経症においてもこの事情には変りはない。

slide 32(略)とslide 33(略) とはそれぞれN.C. A.と喘息との発作時のpolygraphによる呼吸筋マ 電図であるが，両者のそれは全く相似である。射 ち雨者にみる呼吸困難は呼吸筋のdysrhythmia， 特に呼気筋と吸気筋とのrhythmicalな交互活動 が失われ，そのために補助呼吸筋の活動を余儀な くされていることによることが分る。

ところでこのような疾患に癒着性蜘蛛膜炎，そ れも subclinicalで, 顯微鏡的のものが関係すると 何故题つたか。これはよく受ける質問であるが， これも経験によつたのである，従来蜘蛛膜炎とい えば急性では脳资髄膜炎, 特に結核性, 慢性では 空間占拠病㮐の一つである褧腫性乃至瘉着性の蜘 蛛膜资とであつた，それそれ特有な症状と所見と をもち，それぞれ特徴的な疾患を形造つているこ とは周知であるが，その背後に神経症様症状を祕 めているものである。特に前者注精神神経症的， 後者は臟器, 特に心葴神経症的の症状を伴なうこ とがある，実際にこのような例を経験し，確認し ているうちに自然とわれわれが問題としている疾 患が濳在性の癒着性蜘蛛膜炎によるのではないか に思い到つたものである。元してN.C.A.やこれ 類似の疾患に神経学的の所見，特に異常反射を証 明しうる場合のあることを確かめえた。 


\begin{tabular}{|c|c|c|c|c|c|c|c|}
\hline & \multicolumn{4}{|c|}{ 膝蓋腱反射 } & \multirow{2}{*}{$\mid \begin{array}{c}\text { バビン } \\
\text { スキ- } \\
(+)\end{array}$} & \multirow{2}{*}{$\left|\begin{array}{ll}\text { r } & > \\
\boldsymbol{Z} & \ddots \\
(+)\end{array}\right|$} & \multirow{2}{*}{\begin{tabular}{|l}
-1 \\
× \\
低下 \\
消失
\end{tabular}} \\
\hline & 消失 & 低下 & 正常 & 元進 & & & \\
\hline 最 & 4.0 & 15.5 & 24.2 & $\mid 56.4$ & 21.4 & 23.9 & 17.2 \\
\hline 頭 & 6.6 & 13.2 & 27.6 & 52.6 & 15.8 & 20.4 & 16.6 \\
\hline 局 こ & 7.4 & 18.0 & 25.4 & 49.1 & 12.0 & 25.2 & 18.9 \\
\hline 呼吸困難 & 4.5 & 1 & 31.2 & 50.6 & 17.5 & 25.4 & 17.0 \\
\hline 心悸元進 & 4.2 & 16.4 & 25.9 & 50.8 & 18.5 & 26.4 & $\overline{17.9}$ \\
\hline 胸部构感 & 5.6 & 17.7 & 31.8 & 44.9 & 16.8 & 24.6 & 20.2 \\
\hline 痛 & 4.1 & 14.8 & 24.3 & 56.7 & 22.5 & 26.1 & 21.9 \\
\hline 腹部愁訴 & 4.9 & 18.9 & 28.0 & $\mid 48.1$ & 14.3 & 23.4 & 12.3 \\
\hline
\end{tabular}

第 6 図

slide 34, (図 6 ) は，躴述の入院患者で証明しえ た神経学的の所見を各愁訴についても統計したも のである、長神経路障害が好発し易いため，各愁 訴に対して特別の分布はなく，一般に平均してい るが, その頻度は膝蓋腱反射の光進が最も多く約 半数に, 次はHoffman反射の出現で約 $1 / 4 k$, 次は Babinski反射の出現及びMayer反射の消失で共 に1/5に証明された。

そこでmyelography(小西)，文脳法（沢見）, 筋 電図法（益子), petechiodermatography（平川）, 毛細管顯微鏡法（筧）によつて臨床的に，又特に 困難な病理組織学的 (森本, 藤原)にも検索が行 なわれ，今日漸くその病像が判然した。ここでは myelography と病理組織学的との 所見に中心を おいて話を進めよう。

slide 35(図7A), 36(図/B), 37(略)： 本症の myelographyで注意すべきは, 蜘蛛膜変化が微細 であるから䖝光板上で観察しながら造影㓝を移動 せしめなければならない。ところでわれわれが得 ているようなmyelographyの所見は果して意味 があるだろうかとう疑問をよくきく。そこで生 前myelographyを実施した患者で, 後年他の原因 で死亡した例について組織学的検索を行ない, 両 者の所見を脊鹃有の全長に亘つて比較検討した。今 までに 3 例であるが, 全例においてむしろ驚くべ き程の一致をみている.ここに示すslideはその 1 例で, myelographyと組織所見とから得られた 蜘蛛膜癒着 (太横線) 分布と造影剤の停滞模㽷と

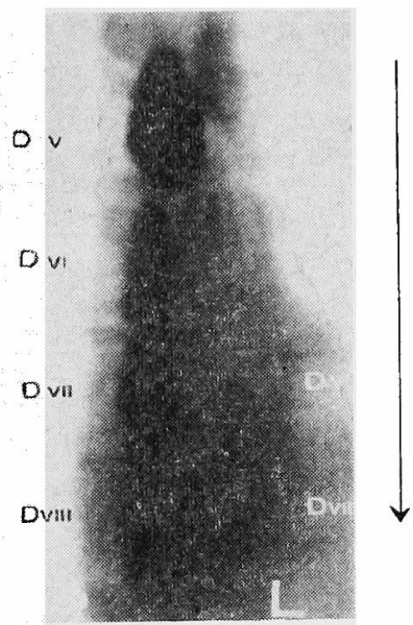

背位頭高 $5^{\circ}$

第 7 図A．TI25才ㅇ

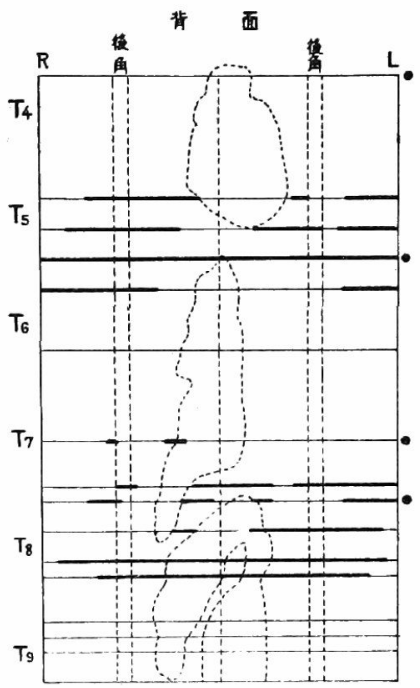

第 7 図B

を合せスケッチしたものである、春䯣は胸部, 癒 着の強い部分は 5-6 及び 7-8の部分で, 造影 剤が癒着の間嘹を縫い，或いは阻止されている様 子がよく分る。

ここで蜘蛛膜及びそれに隨伴する神経細胞の組 織像を供覧しておこう。

slide 38 (略)：健康な成人の倁蛛膜は内層々 外層細胞の 2 層からなる菲薄な膜である.

ところでこれら患者では一般に蜘蛛膜, 柔膜及 


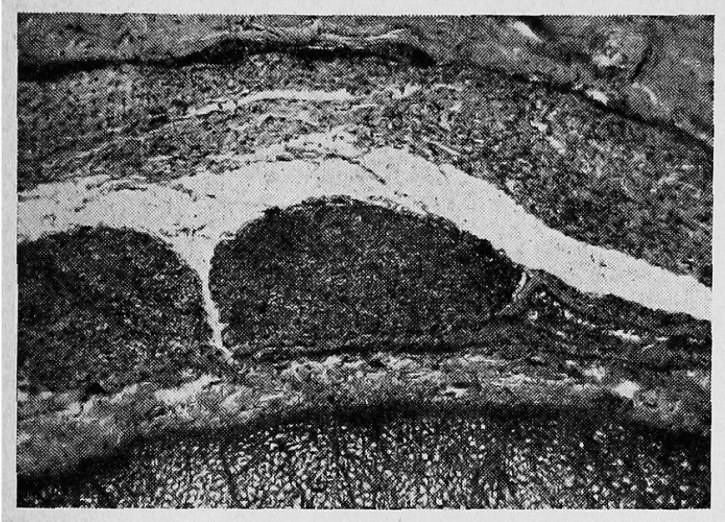

第 8 図

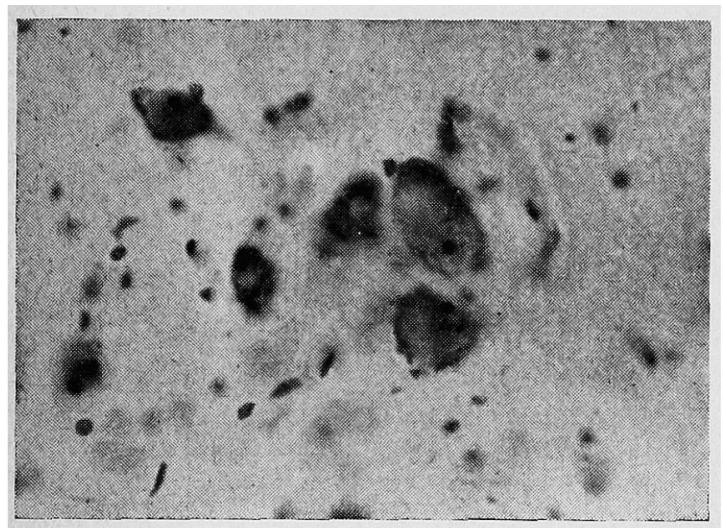

第 9 図

び線維杜間に強い線維性変化が見られ，神経根は これに囲繞されている。

slide 40 (略)：そして時に小さな楚腫形成も ある。

slide 41 (略)： 漏斗部においては神経周囲炎 の像が著明である。

そして脊髄内神経細胞はNissle染色において蝴 蛛膜の変化部位に相当した高さのnucleus intermediolateralis superiorの尖端群に最も高率に変 化が見出された。

slide 42(図9)：その変化はchromatolyse, 腫脹, 変形, 核の移動等の重篤变化及び (slide 43, 略）退行性変化である.

slide 44(略)： 脊髄神経節においては外套細 胞の堌殖, 細胞体の空胞形成, Gefensterte型, ch-

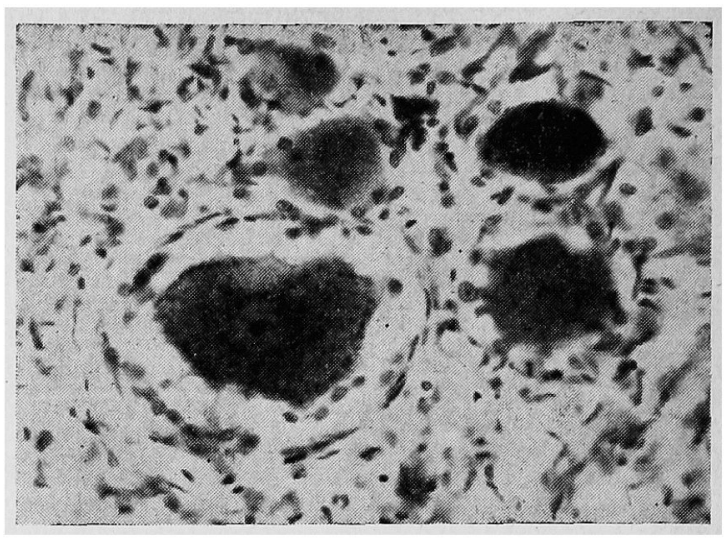

第 10 図

romatolyse, 濃縮, 核の移動, 濃染, 萎縮等の重 症変化やneuronophagy或いは崩壊の像がしばし ば認められた（図10）。これ等の組織所見によつ て問題の疾患が自律神経の失調や疼痛を主徽とす ることがよく理解されよう。

そこで臨床症状と myelographyの所見との対 比であるが，これは各脊椎の高さにおける腹面と 脊面の癒着頻度を百分率で、該症状をもたない場 合のをれ之対比し，統計処理を行なつた。以下の slideで三重丸は危険率 $0.1 \%$ 以下，二重丸は $1 \%$ 以下，一重丸は $2 \%$ 以下，黒点は $5 \%$ 以下を以て 有意であることを示す。

slide 46(略): 呼吸困難群144例, 腹面は $\mathrm{C}_{3 \sim 7}$, $\mathrm{Th}_{3-6}$.

slide 47(略)：心悸六進群103例, 腹面で $\mathrm{Th}_{3,5}$, で対照群 115例に対し有意, 背面は何れの場合も 癋着頻度高く，特徵的な分布はみられなかつた。

slide 48： 各愁訴について上述のような統計 処理を行なつたものの表示で，上段が腹面（図11 A），下段が岺面である(図11B）。これでみると N.C.A.は頸, 上胸部, 腹部神経症は下胸部の癒 着性蜘蛛莫炎があることが明瞭になると思う。そ こで（slide 49・50，図12A・B）孤立性不整脈 25 例を対照 629例について同様の統計処理を行なう と, 腹春, 殊に後者において和 $\left(2 \%\right.$ 以下), $\mathrm{Th}_{2-3}$ （ $0.1 〜 0.2 \%$ 以下）の癒着が有意義であつた。

さて弧立性不整脈は心電図で変化が証明される 故に神経症ではない。しかし心臓に器質的変化は 
腹 蕰

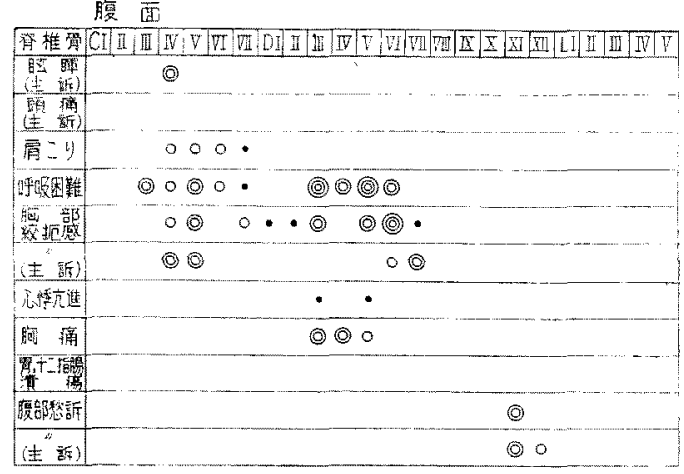

第11図 A

背 面

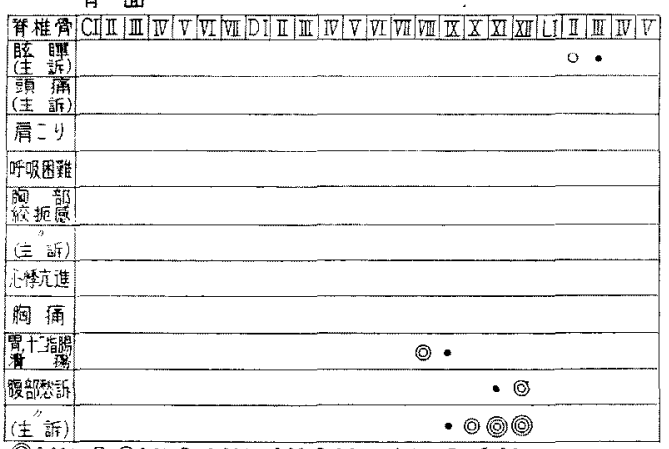

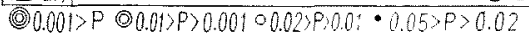

第11这 B

見出されない，師ち機能疾患と考えられる，そこ でN.C.A.及びそれ類似の疾患も心臓に器賀的変 化はないが機能的の変化は諗められる，促つて今 日多くの心葴病学者はこれを知張り神経症とは考 えずに機能疾患とする。しかしわれわれの調べた ところでは，この種の疾患には精神分析法を用い て115名で精查したところによると図13に見るよ うに凡ゆる種類の神経症が強迫神経症を除いて可 成りの頻度で存在する，勿論弧立性不整脈の如き patternの幅の㷋いものではこの限りでなく，愁 訴を全く客観的に記述する。この理由もわれわれ の発見した臨床下癒着性蜘蛛膜炎の所見によつて 明らかとなるであるう。師ち蝴蛛莫炎屾系統疾患 の一つであつて，原因は不明たとしても春䯣許り でなく脳，特に脳底からSylvi氏溝にかけてその 病巢をもつことは周知の通りである，又事実気朕

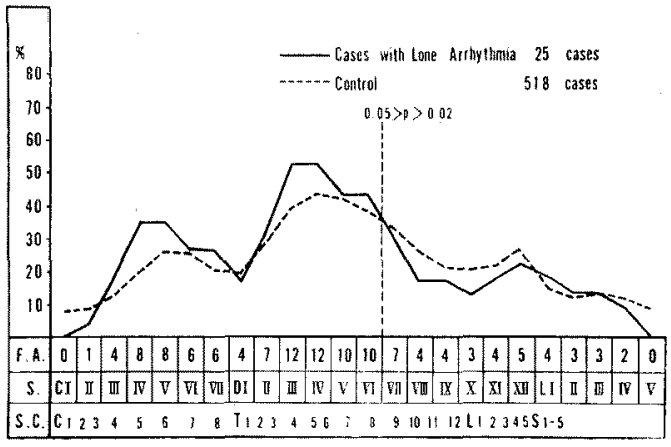

图12A. Myelography-Ventral Aspect

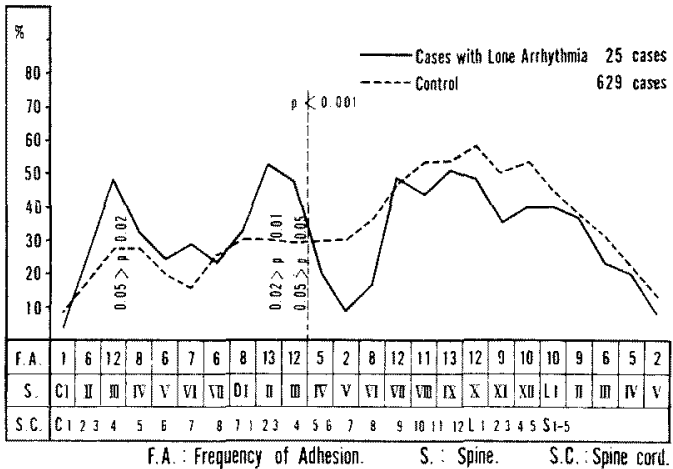

图12B. Myelography-Dorsal Aspect

\begin{tabular}{|c|c|c|c|}
\hline & 舁 & 女 & 䛨 \\
\hline 不晏神程症 & 38 & 9 & 47 \\
\hline 不安七ステり一 & 14 & 20 & 34 \\
\hline 神経䔬弱 & 19 & 4 & 23 \\
\hline 檕换七ステッ一- & 1 & 9 & 10 \\
\hline \multirow[t]{2}{*}{ 強迫神経症 } & 1 & & 1 \\
\hline & 73 & 42 & 115 \\
\hline
\end{tabular}

第 13 図

法によつて高頻度に，しかも或者は明らかに進行 性の脳萎縮，眚ち脳室や脳浗の拡大がみられる。 次の図はこれを示す。

slide 52 (図14A)

slide 53 (因14B)

師ち前頭連合野やlimbic，特に海馬回転の障害さ れる可能性が考えられるのである.

以上心缄神経症やそれ類似の疾患，特に孤立性 不整脈が循環系の専門領域を遥かにはみ出すこと 


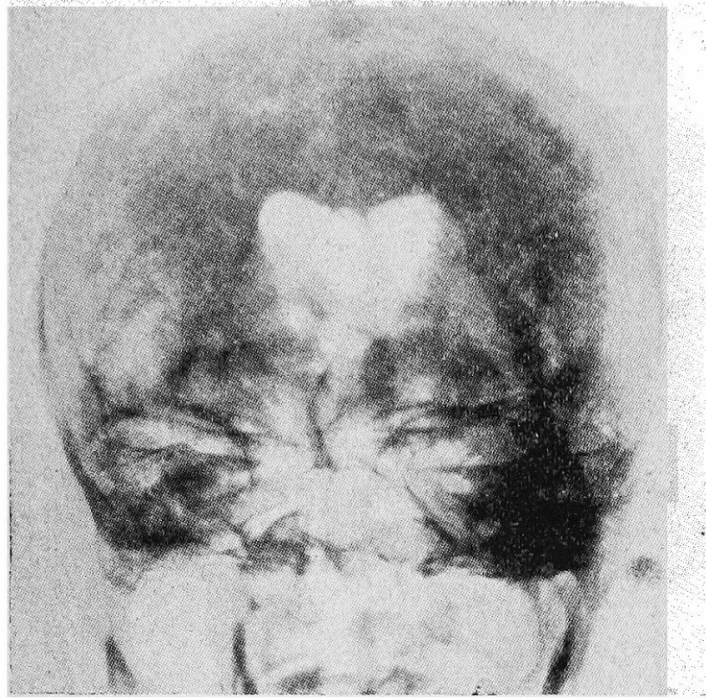

図14 A

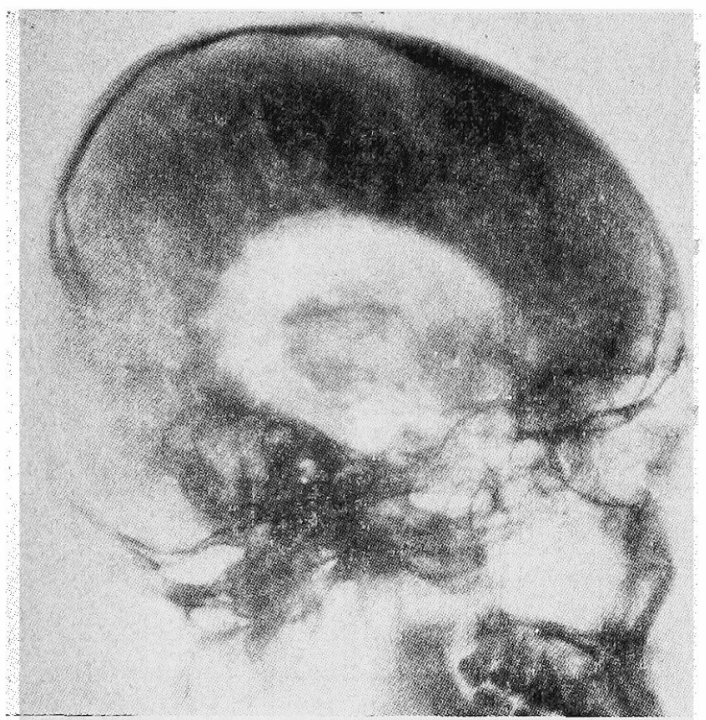

図 $14 \quad$ A

は，事実として動かし難いところであろうと思 う.

第 4 章として最後に少し違つた方向から問題を 取扱つてみよう。それは組織アレルギーの問題 である20) 27)，今日の言葉でいえば自己免疫であ る。そしてリウマチ及びそれに関連する疾患に重 要である，節ちリウマチ性心炎，腎炎及び膠原病 である．わたくしがリウマチの研究に着手した当

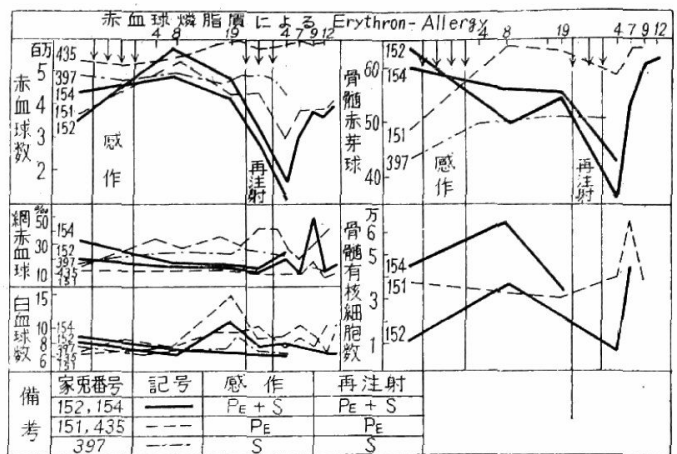

図 15

\begin{tabular}{|c|c|c|}
\hline \multicolumn{3}{|c|}{$\begin{array}{l}\text { Erythron-Allergy } \\
\text { の抗原分析 }\end{array}$} \\
\hline 感＼cjkstart作 & 再注射 & 貧 血 \\
\hline $\mathrm{P}$ & $\mathrm{P}$ & - \\
\hline $\mathrm{P}$ & $P+S$ & - \\
\hline $\mathrm{S}$ & $\mathrm{S}$ & - \\
\hline $\mathrm{P}+\mathrm{S}$ & $\mathrm{P}+\mathrm{S}$ & + \\
\hline $\mathrm{S}$ & $\mathrm{P}+\mathrm{S}$ & + \\
\hline $\mathrm{P}+\mathrm{S}$ & $\mathrm{P}$ & - \\
\hline$P+S$ & $\mathrm{~S}$ & - \\
\hline
\end{tabular}

時は未だアレルギーを免疫と区别する明確な概念 がなかつた ${ }^{20)}$ ．アレルギ一性疾患の確定に一時期 を画した馬杉腎炎でさえそれを指導した思想は全 く免疫の概念であり, 臓器細胞を抗原とした血清 抗体によつて直接腎炎が薏起されると考えられて いたわわたしはこの馬杉腎炎を考䓩して ${ }^{20}$ ), この 一次反応は単に抗原(家鴨血清)を腎に固定するに 過ぎず，腎炎はその後の異種（蒙鴨）血清に対す る局所の抗体製産によるのであろうと推論した。 そしてアレルギーとは細胞の固有成分を決定分子 群とした免疫反応であると結論し，nephronにか えるに単一遊離組織である るrythronを以てし， 赤血球のphosphatide分画をHapten，異種血清を Trägerとして実験的Erythron-Allergy ${ }^{24)} の$ 作製 に成功したのである。

slide 54(図15)： 師ち家鬼において牛赤血球 燐脂暨々牛血清とを用いて感作，再注射を行なう と，太線でみるように末梢血のみならず骨䯋の赤 
牙球も著明に浌少する，しかし網状赤血球は貧血 の回復期にのみ上昇し,白血球系には变化はない， 点線は対照実験, 邲方燐脂質のみ或いは血清のみ で感作，再注射を行なつても変化は抢こらないこ とを示す，佾このことを一層詳細に检したものが slide 55 (図16)の表で，これによると赤血球燐脂 䆩はHaptenの性格をもち，それ自身では抗体の生 産能力はなく，只由来する細胞一の抗体の特殊性 を定める決定分子群であることが分る。そしてこ の分子群は微量ながら血清中に遊離しておりこ れ自身では急性のErythron-Allergyを惹起 し得 ないが, 感作は可能であり, 若し濃暻に長期使用す れば慢性のErythron-Allergyを惹起し得る可能 性がある．今日かかる組織成分は抗体生産者にと つて自己と考えられる故をもつて，これを自己免 疫と呼んでいる。しかし理論的にも又実際的にも 組織や細胞は種属の如何を問わず生体一般に共通 であり得る，征つてこの名称は必ずしも正確では ない，垖ちこの赤血球燐脂質は種属特異性を持た ない. 垖古魚類 (雷魚), 両棲類 (蛙), 鳥類 (鴙, 七面鳥), 哺乳類 (牛, 馬, 豚, 羊, 犬, 蒙鬼) 由 来の赤血球燐脂質は何れも同一実駼動物において Ery thron-Allergy 同一又は交必の形でおこし 又脱感作する。

slide 56(略) は鷑の赤血球燐脂質が牛のそれに よるErythron-Allergyを脱感作しうる垁験を示 したものである。

然し実際的にいつてかかる細胞燐脂質が外部か ら供給せられる可能性は極めて少ない，あつたと しても自己のそれで十分有效なのだから問題とな らないであるう。それでかかるアレルギ一を自己 免疫己呼えでも実際的には少しも差支えないよう に見える。わたくしも当初はかかる名称を用いて いた。しかしこの名称の矢点はこの方面の研究進 路を俱まらしめる恐れのあることである。という の法かかる決定分子群，それ注多論細胞phosphatideに限らないであろうけれども, 単にHaptenで あつて，それ自身は抗体生産能力をもたない，即 ちこれがアレルギーの完全抗原であるためには

\begin{tabular}{|c|c|c|c|c|c|}
\hline 感 作 & 翼血 & I 再注射 & 貧血 & II 雪注射 & 資血 \\
\hline 牛赤血球 & - & 牛赤血球 & - & $\mathrm{P}+$ 牛血溜 & + \\
\hline 羊赤血球 & - & 羊来晌球 & - & $\mathrm{P}$ 十羊血清 & + \\
\hline 羊赤血球 & - & 羊赤血球 & - & $\mathrm{P}+$ 牛血清 & - \\
\hline
\end{tabular}

网 17

Trägerは少なくとも異種，或いは同種でも型別の 物質乃至は分子内構造の変化をうけた自己物質で なければならない。この間の事情を分り易くする ために次の実験を示そう。

slide 57(略)：今家乘に扔いて牛の赤血球て 感作し，再注射に牛の血清を用いたのでは，既述 のようにErythron-Allergyは起こらない。しかし 赤血球の燐脂質と牛血清とを結合したものを注射 するとこれが起こつて来る，的ち溶血性貧血では なく再生不良性貧血が起こるのである。 slide 58 （図17)は牛の外に羊の場合交び牛と羊とを交文し た場合を示してある。

この成績からすると燐脂貿は種属特異性をもた ないのであるから，細胞乃至組織アレルギーに重 要なことはTrägerが感作と再注射とでmatchす ることである。そしてこの実験が教えることは， 若し赤血球のうちに存する獜脂質Trägerが何等 かの変異, virus 伝染又は突然変異をうけて異質 化すると，そこにErythron-Allergy節ち再生不 良性貧血㤎惹起しうる可能性があるということで ある。

時間の都合上詳論は出来ない怔， Burnet ${ }^{29}$ の “Forbidden Clone” Hypothesisは突然变異によ つて “Clone”（最近はThymus）が自己免疫体 を生應すると考えるが，これは本末を転倒してい るのではなからうか。

slide 59 (略), slide 60(略)：因多にErythron-Allergyに扔ける燐脂質の有效成分はFolchの 牛脳で行なつた chloroform-alchohol法で分画し た第I分画，師ちinositol-containg phosphatide にある。

slide 61(略)：われわれはこれまでEryth- 


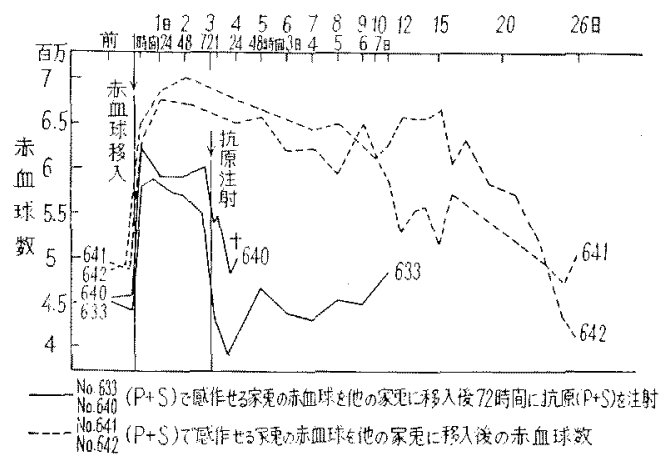

図18. Erythron-Allergyの执体の追究 その1

ron-Allergyの外に同㥞の方法でこの表に示すよ うに白血球，リンパ球，沉血球，心筋，腎，脳灰 白質，㨫白質及び旰等で細胞万至組織アレルギー を感作することに成功している。

slide 62 : 又Erythron-Allergyの抗体は感作 された赤血球に結合していることはこのslideで 示される通りである。郎ち再感作された赤血球を 32Pで標識し型適合の他の家秉に移入し，そこで Erythron-Allergyの起こることをみている（72 時間後).

然しCoombs試験证接，間摸ともに確実に陰 性であり，果してこの抗体が促来知られている 抗体であるかどうかは不明である。わたくしは 諸般の焘情加方赤血球白身で生座され，赤血球白 身の構造蛋白が抗体化しているのではないる考 えている。

以上のようにallergyの道は未だ遠い。現在り ウマナ疾㭧は $A$ 群队型溶連菌によると考えられて いるが，それが如何なる理由でアレルギー抗原に 転化するか，又リウマチの急性と慢性とではその 病像経過が著しく罢るが，それは如何なる理由に 基づくのか，佮十分明らかでない，只Kaplan²8 は 5 型の溶連菌のM蛋白分屑が人心筇上免疫的に 交文反応をし，そこに白己免疫の可能性を考えて いるが，急性りウマチはともかく，慢性のそれは 未だ問題が残されている。況んや翏原病において は一層この感が深い。

以上のようにアレルギーの閏題も循環系の垑外
に遠くはみ出す，而もリウマチや膠原病は循環系 にとつては主要な課題の一つである，それでも䏌 循環系尃門の孤城を敢て死守卞拿気があるであ らうか。

さて以上のように循環系においてもその問題を 正当に解こうと思えば尃閏分野にのみ閉じ箔つて いては到底不可能であることが分るであろう。と いつて今日内科分分科分科を重枚つつあるの は，そ彻当の理由のあることで，今更一人で内 科全域に亘る責任をとろうとしても，それは到底 不可能なことに違いない，そしてこのような矛盾 は他の医学の領域においてもそうであるうと思わ れる、鉂つてこの点われわれの責任を有する内科 の領域においてをの解決策を考えることは決して 無䭾なことではないと信ずる。

しかし上記のような状態は医学が末だ完全な発 逵を遂壮ていないためで，凡てのことが既知とな

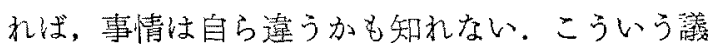
論当確かになり立つ、そうな机は医学を多くの専 閒分野に細分し，尃門的な知識と技術とを教育す れば，丁度工業製應におけるように，医業も正確 且つ迅速に遂行出来るに違いない，そして医業夺 computer Eautomationによつてマス・ブロ寺 代に這人るか子知れない，そしてこのことは医学 の社会化のために確かに必要であり，その努力は 当然であうう。そして若し現在信ぜられているよ うに身体に作用する自然法則が物質界におけるよ うな白然因果律であれば，医学の社会化のみなら ず医学そのものの解明に確かに不可欠であるとい わざるを得ない，凡てが知りつくされ，技術も無 限に発達しうると予想され得るからであり，電子 頭媨には疲学々 careless mistakeがないからであ る。

然し果して医学，特心臨床医学の最も重要な部 分がこのような機械化，オートメ方出来るであう うか.素朴な直感においても答えは'No'であるう。 何故应ら矤学杜細分出来ても人の身体は細分出 来ないからである. 尤も細分し，人工藏器の試み もあるようだが，然し本当の意味での細分，即ち 
要素的細分と再構成は決して出来ないであろう。 それは既に指摘されたように生体における平衡は 決して静的なものではなく動的であり，䦎鎖系で なく開放策だからである，即ち身体では単なる因 果律でなく，それ以上の別な自然法則13)，それに よつて意識郎ち主観，もつと適切にいえば創造と いう機能が発生するような法則が作用していると 考えられるからである。それが何であるかむすず かしい議論を抜きにして，上にわたくしが述べた 実例によつて験証してみよう。

まず注意して頂き度い事実は心不全にお㧍る強 制利病と高血圧症における强制降圧の処置が共に 1 日尿中のC.A., aldosterone, 時にはglucocorticoidを増量することである。この事実はHans Selye ${ }^{31}$ のG-A-S (general-adaptation-syndrome) に通ずるものである. 又Selyeは高血圧症や心不 全を糖尿病やアレルギー性疾患同様stress病に数 える、しかしわたくしの昔からの疑問はかかる G-A-S，一むしろG-A-reactionの方がよいと思

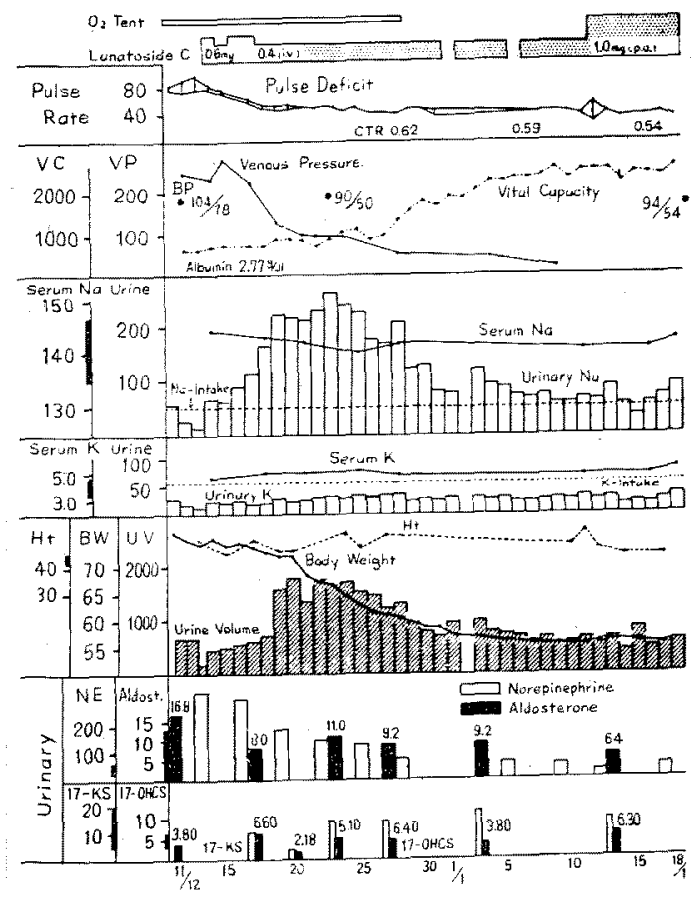

図19. T.Y. Decompensation IV 60-y.m. Coronary Heart Disease
うが，何故あるものでは高血压症，あるものでは 栯尿病又他の場合はアレルギーという特殊な疾患 を結果するのか，師ちG-A-Rにおけるspecificity の問題である.このことを理解するため次のslide を御覽願い度い。

slide 63(図19)：症例 1 であるが,これはシギ タリスと酸䋕テントで治療し，当初 1 日尿中のal一 dosterone，C.A.は著明に，17-OHCSも僅加に増 量していたが，利尿がつき，静脈圧が下り，肺活 量が上り，体重が減少するにつれ、これらも速やか に正常值に復している。强制利尿時とはむしる正 反刘の反応である、かかることは安静利尿の時も そうである。何故か，理由は明白でこの際の利尿は 原因療法によつており，強制利尿ではないからで ある。強制利尿では原因が治療されず，その上強 制的に利尿するのであるからstressは倍加する。 それ故G-A-Rが高まらざるを得ない。この筆法で ゆくと高血俚症における減塩 やthiazidesの降代 処置も確かに stress，即ち原因に向けられすし て単なる対症処置といわざるを得ない。そして， このことは原因の分明なCushingやacromegaly， 臂舌蜸炎においても正にその通りであつたが，本 態性といえどもその疑は十分にあるといえる。

さてそこで閴題のかかるG-A-Rのspecificityで ある、G-A-Sにspecificityを者えること自体が矛 盾している、年事実として同しG-A-Sとしての区 応が前者では心不全に，後者で法高血压の驖塩潦 法に結合する。このことはSelyeの寒冷, 伝染等觜 同様である。では何故か。この解答は至難である が、これらのhormonesの性質から考えて生体 が族病の原因を解決するに必要なenergy とその 作用のための昜，邲ち内部環境を作り出すための 一般条件として考えられる。この故にこそこの G-A-Rはあらゆるstressに共通に発現し，病理的 というよりはむしろ生理的と考兄られるべきもの である．従つてこの反応から高血压症や糖㽷病や アレルギー性疾㭧等の特殊条件は決して導き出さ れはしない，勿論このようなG-A-Rはそう簡単な ものでなく，例えば次に示すhydrocortisoneの 

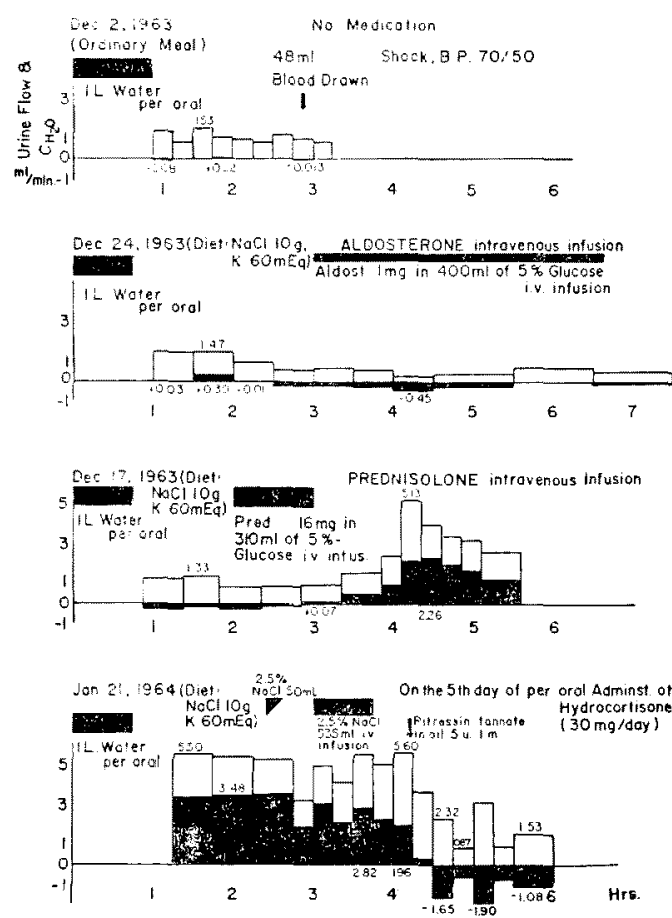

区20. Urine Flow and Free Water Clearance in Water Loading Test under Various Conditions in a case of Posthypophysectomy Syndrome (N.I. 31 v-o. Male)

antidiuretic hormoneに対する拮抗作用等ま未だ 明らかにされていないところであろう。この成績 は末発变につき共同研究者音明寺央，粟村政昭両 君の名前をあげておく。

slide 64(図20)： N.I., 31才, 男, 下㨫体切除 後定候群, chromophobe pituitary adenomaて 昭和37年 9 月中旬に下垂体腫瘍の $2 / 3$ 以上を切除, 10月手街㣪の症候群で入院.

slideの上段は無処置時の水試験, 水利尿なし. slideの第 2 段は 1 日 Na $170 \mathrm{mEq}, \mathrm{K} 60 \mathrm{mEq}$ とし 水試験封にaldosterone $1 \mathrm{mg}$ を $400 \mathrm{ml} の 5 \%$ 菊葡 糖液に大れ点滴静注, や注り水利尿なし。

slideの第3段注同様の水試験㭙にprednisolone 16mgを同様にして点滴静注すると約 1 時問のずれ を以て可成りの水利尿を見る。

slideの最下段は予め 1 日30mg のhydrocortisone

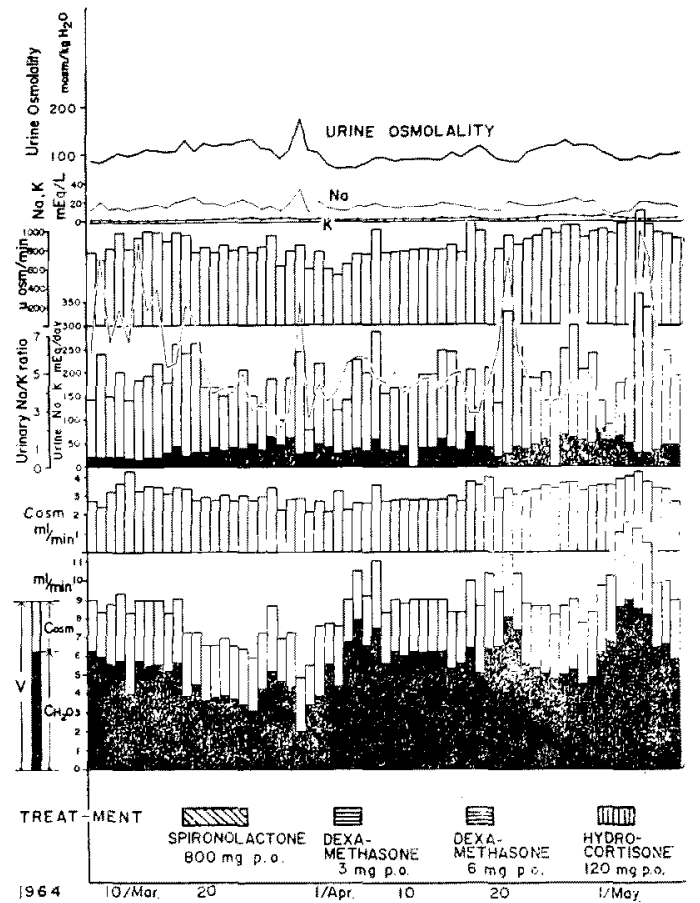

图21. K.O. 31 y.m. Diabetes Insipidus -3

を径口的に㪗与，第 5 日目に同様の水試験，著明 な水利尿㐫り，そこでRobin-Carter試験を行な うに勿論効果なし，次いでPitressin 5 uを筋注， 水利尿著明に抑制され真のclearance となる。

slide 65(図21)は31才，男,外賃後尿崩症に皘極 的にhydrocortisoneを与えその利尿をみたもので やはりこれでも著明に水利尿加璔すようである。

以上のように生体の反応は決して単純な刺激に 対する区応，物質における作用と区作用の法則に 従つてではなく、より複雑な，而も過去の歷史に よつて条件付けられ，むしろ刺激或いは原因学 問題としてうけとり，問題を解くという形で行な われているように見える。師ち慢性槐血性心不全 とは心臓が与えられた条件に対して問題を解決し うる限界を示しているものである。何故なら少し 以前には同じ条件に対して心眮は自らのスターリ ング法則によつて問題を解決していた。この時期 がいわゆる代侸期である，然るに同じ問題が今や 自らの法則のみでは解決し得ずして広く身体のG- 
A-Rに援助を求める. 然しこの際と踓も捺制的の 反応ではなくそれそれの体孹に相当し，又その生 体の歷史的な条件に従つて行なわれるようであ る。この事実は䠶还のようにかかる心不全の患者 を峃なる強制利尿郕によつてではなく,安静, 酸琴 テント或いはジキタリス等で治療した場合，そこ に結果される利尿效果は殆ど常に同一であつて，

C.A.は下降し, aldosterone 減少し而も利尿剂を 用いずとも見事なNa利尿のあることで知られよ う. 又この事実は心不全の癔法に重大な教訓を 与えている，師ち心不全においては問題は飽くま で身体と同様われわれ医者も心臓に関する問題を 中心とすべきであつて，利沓処置はあくまでもそ の補助であり、これを前景に持ち出す主張は当を 得ないばかり名険でさえあり得る。これを策際 に示すものが不応性心不全であることは前迅した 通りである.そしてかくの如く問題を愦つて解く と，その結果は循環系の不全の域を遥かに越えて 重大な全身性の代償不全をさえ結果するのであ る.われわれは身体の解こうとしている問題をよ く理解し，その方向に手を貸してやらねばならな 心、決して薬物の作用を身体に強制してはならな いのである。

次の高血圧症の問題は心不全が心とその後方の 蹱害に刘する問題の解き方であるに対しこれは 心葴々その前方障害における問題を示す．今日文 明国で高血圧症性疾患が疾病死の第 1 位にある ことは周知である.この理由はいろいろあろう が，その最大のものは本症がそれ自身長年月何等 の障害も呈さず, 症状を呈する際には既に脳, 心，腎に重大な障害を結果しているためである。 何故か、循環系は心の徯方では自律性が弱く，心 の前方では自律性が強いためであると考えられ る. 現在動脈管は体，肺，腎等において可成りの 血圧範囲内で高い自律性のあることが殸められて いる.われわれはこれを既述のように心藏法則と 並び動脈法則（勤脈平滑筋の）と呼んでいる。そ して血圧はこの心藏と動脈との法則によつて広い 領域に亘つて自律的に解決される。一種の代償期
である。そしてそれを褧付ける事罢が前述の種々 の高血圧症㭧者の降任処方において示した一連の G-A-Rである.この際沈心不全時と異なりその反 圭法却つて治療処置に抵抗するようにみえる。師 方減塩やthiazides でaldosteroneやC.A.が上昇す る. 然し処置以前の状態では一般に, 特に不態性 高血圧症ではこれ等の値は高くない，即ち頸動脈 洞々同㧼，凡ゆる血王調節子は高血王状態に㧍い てそれ程stress受けているわけではない。つ まりこれらの系は心脈管系ATPase-ATP 系の機 能血進（心脈管肥大）によつて高血圧の状態に順 応し再設定されているように見受けられる。この 故に現在高血坧を一つの疾病と見ず，身長や体重 の如く統計分布における上限を意味するに過ぎな いとのPickering32)の如き見解も生ずるのである。 然しこれはその予後の示す如くやはり立派な一つ の疾患である。身体が与方られた高い自律性と開 放系エネルギ一系であるために，却つて宿命的な 疾病の方向に向つて問題を解いている状態という べきであるう，従つてその治療は最早身体の可能 性の限界を越えており，遙加に次元の高い身体の 作用, 師ち意識の協力を必要とするのである.

筆 3 章の心臓神経症及びそれ類似の疾患埂に このことを如春に示す。神経症とは器質的原因な くして心因性に惹起された疾患であるといわれ る. 然し今日の方法と知識で誰が「器質的原因の ないよいう確定的な制断を下し得られようか。 器筫的とは知識と方法との函数である。われわ れの発見した蹈床下の癒着性蜘網膜炎とは細心 の注意によるミエログラフィー，EMG，PEG 及び組織検查によらずして発見は不可能なのであ る。身体の解きえない問題は意識が解名ね怔なら ない，然るに患者の意識は勿論のこと医者の意識 もとれを解き得ない，否解こうとしなかつた。 れに神経症の発定するのは全く当然ではなからう 加。

第 4 章のアレルギーの問題は身体が問题を解き 鿁る例である。身体の法則は決して目的論的では ない，身体の保全のために設計せられた機構も正 
にその絶妙な機構の故に却つて疾病を招くことが ある、抗体という抗原特異性の蛋白生㝢機構はそ の余りにも絶妙にすざる機構の故に却つて俱つた 答えを出す。それ卯ちアレルギーであり，いわ ゆる自己免疼である。即ち身体には自然の物䝷的 法則である因果律は橆諭支配する。そしてその因 果律はそれ自身身体の保全と注盤関倸であり，そ の根本課題が分子の問題にあり，そして今日の病 理学が次第に分子医学の方向をとりつつあるのは この故であろうと思う、アレルギー等はそれの適 例である，師方抗体の決定分子群をとりかえるこ とによつて免疫は180度の方向を变えてアレル ギーとなるのである。

では何故身体は与えられた一つの刺激を単に刺 激上してではなく、これを問題として受け取り， そして単なる反応ではなくして解答として反応す るのであろうか。卆れは決して調節作用とか制御 作用とかいう単純な号のではない。問題を解くと いうことは意識の領域においては日常茶飯事であ り，その方法も周知である。即ち帰納法と呼ばれ 日常の常暜加ら精密な凡ゆる自然科学, そして先 験的たといわれる数学まで等しくこの方法によつ て問題を解いている，そしてわれわれは今身体も この方法によつて問題を解いているのではないか という感を深くする. 然し身体の内部環境の現象 は意識下にあり，葆つてこれを意識の指導下に遂 行することは出来ない。しかし意識だとて未知の 問題を解く場合には誾納法の全系列を意識下にお くことは出来ない，即ち無限の系列を一瞬の間で 飛躍する直観，邲ち無意識部分が不可欠である。 又その故に新しい，これまで嘗て存在しなかつた 意識が創造されるのである。わたくしはこの無意 識部分の帰納法を帰納律 ${ }^{13} 32$ 々呼んでいるが，二 の帰納律がすでに身体反汒のかかる部分にも作用 していることを知るのである。

さてこのような問題を解くという形の帰納律が 身体に働き，医学はこの身体の帰納律を巧みに利 用して疾病を治療しなければならぬことを知つた が,然しかかる力法は決して新しいものではない。
医学の根底にある原理は古来この事奏を巧みに利 用したことによつて成功しているのである，師ち 身体が解き得ない問題を探究しその原因を除去す る.そしてそうすることによつて，身体をして自 ら問題を解決せしぬるようにする。伝染病におけ る抗生物質に始まり癌に至る外科療法にいたるま で今日の医学の処置は悉くこの手段によつている のである，医学は疾病の治療に穖械修理の如く最 後の一つの鋲に至るまで手を貸し世話をやいてい るわけではない，只身体が自らの力で問題を解き 得る正にその線まで手助けをしているに過ぎな い. 勿論今日の医学はその方法において格段の進 歩を成し遂げているが，然しその原理においては 少しも変化はないのである。この点医学は自らの 力を過信してはならないのである。そして今日ま だ解決のつかない多くの疾病, そしてそれは殆ど 凡てが内科に集中しつつある今日，かかる原理を 背景とする科学的な疾病追及が切に望まれる。畋 ち身体注何を問題とし如何にそれを解こうとして いるか，そしてこの分野こそが尃門化する今日の 医学に共通の問題であり，内科学の原理であるう と信ずる。

そこで結論を述べう。疾病は決して労純な自 然因果律によって現象しているものではない，身 体注病の原因を問題として受取り，それを触答 するという形で反応している，若し完全な解答が 得られれば，そこに発病ということはない，自然 免废や心臓の代償等はその例である，然し若し解 くこと汃困難か或いは不能な場合，そこに疾病状 態が成立する。加か場合，医学は患者の意識に 代つて，その症状と所見とからその原因を知り， 可能な際にはこれを除去してやらなければならな い．身体が自らの力で解法を得るようにするため である.現在の療法は多少ともにこの範疇にある ものだが，特に抗生物質や外科手術はこの適例で あろう、そして医学はこの目的を一層成功に導く ためにまず技術に従つて分科し，次いで効象に よつて専門化した。 そして自然科学々其に長足の

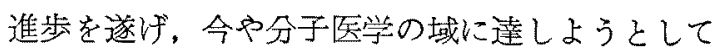


いる。然しそれにも拘らず，現代医学は何無搳識 のうちに身体が自分自身の法則に往つて自らの障 害を修復し得る力を背景にもつのでなければ成立 し得ないのである。勿覦この方向の医学の進少は 今後も続くであるう。然しその限照方玩に徐尺に 顔をもたげつつある事䒠は，わたくしの既に指摘 した通りである，促つて医学が自らの道を完成し ようと思えば，医学本来の基盤である身体の法則 を自敩にもならし，医学本来の科学を，従来の白 然科学の上に建設すべきである。ててしてこのこと は医学を代表する内科学の責任であり，且つ専門

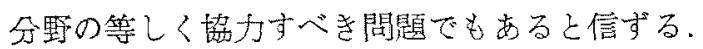

\section{参考文献}

1）前川质二郎：心不全の取近の䗷法，第16回日本

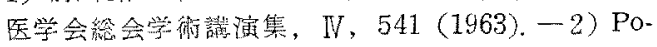
pper, H., \& Schaffuer, F.: Liver: Structure and Function, McGrow-Hill Book Co., N.Y., 1957, Page 3. - 3) Richardson, D.W., Myso, E.M., Magee, J.H., \& Cavell, G.C.: Circulatory Effects of Guanethidine, ect., Circulation, 22, $184(1960)$. - 4) Page, I.H.: The mosaic theory of hypertension, Essential Hypertension, An Intern. Symposium, Springer, (1960), Page 1. -

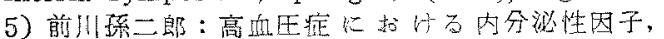
日本内分泌学雑誌，38，778 (1962). Maekawa, M.: The Role of Neurohormonal and Endocrine Participation in Essential Hypertension, VII. International Congress of Internal Medicine, Georg Thieme, Vol. 1, 101 (1963). - 6) Conway, J., \& Lauwers, P.: Hemodynamic and hypotensive effects of long-term therapy with $\mathrm{ch}$ lorothiazide, Circulation, 21, 21 (1960). - 7) Freis, E.D.: Mechanism of the antihypertensive effects of diuretics. Clin. Pharmacol. \& Therap., 1, 337 (1960). - 8) Beavers, W.R., \& Blackmore, W.P.: Effect of chlorothiazide on vascular reactivity, Proc. Soc. Exper. Biol. \& Med., 98, 133 (1958), - 9) Friedman, S.M., J.D. Jamieson, \& C.L. Friedman: Sodium gradient, smooth muscle tone, and blood pressure regulation, Circulation Research, 7, 44 (1959). -10) Mendlowitz, M., N. Naftchi, S.E. Gitlow, H.L. Weinreb, R.E. Wolf.: The Effect of Chlorothiazide and its congeners on the digital circulation in Normo Tensive subjects and in Patients with Essential Hypertension, Annals of the N.Y. Academy of Sciences, 88, 964 (1960). - 11) Peterson,L.H.: Introduction on Symposium on Regulation of the Cardiovascular System in Health and Disease, Circulation, 21, 739 (1960). - 12) Maekawa, M.: Hyper- tension, Its Causal Aspects, Japanese Circulation J., 17, 153 (1953). - 13) Maekawa, M.: The Law of Generation of Consciousness and Neuroses, Particulary Cardiac as a Problem of " $\varphi$ "-ology, Acta Sch. med. Univ. Kioto, 28, 118 (1950), - 14) Maekawa, M.: N.C.A. and Subclinical Arachnoiditis Adhesiva Cerebrospinalis, Jap. Circulation J., 18, 249 (1954). - 15) Maekawa, M., Hayase, S., \& Mashiko, N.: Mecharism of Dyspnea Associating N.C.A., Ibid, 23, 19 (1959). - 16) Maekawa, M.: Angina Pectoris, Its Diagnostic Aspect, Ibid, 20, 457 (1956), 日内 会誌, 45, 815(明31). - 17) Maekawa, M., Hayase, S., Konishi, N., Mashiko, N., Kakei, Y., \& Kawamura, Y.: Clinical Observations on the Atrial Fibrillation, Paroxysmal Tachycardia of the Lone Arrhythmia, Ibid, 24, 803 (1660). - 18) Maekawa, M., Hayase, S.: False Impression of Equilibrium Associated with N.C.A. and Allied Disease, with Special Reference to "Neck Vertigo", Ibid, 27, 213 (1963)。 - 19) 前川孫二郎,

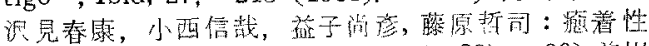

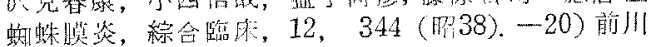

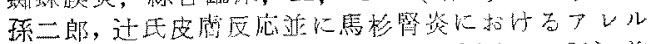
キ一一の問题, 医界過冁, 342, $343(1941)$ - - 21) 前 川係二郎：心筋降碍, 日内会誌, 37,67 (昭24). 前

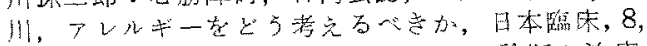

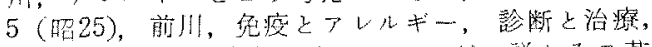
36，91 (炤23)，前川，私のアレルギー説とその基

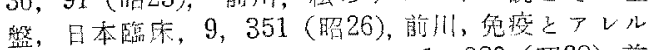
キ一の本犋的成係，アレルギー，1，280 (昭28), 前

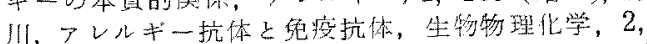
177 (昭30). - 22) Maekawa, M.: Allergie und Immunität, 1st International Congress for Allergy, Zurich, S. Karger, 25p. (1951). - 23) Maekawa, M.: Myocarditis and Allergy. Acta Sch. med. Univ. Kioto., 28, $195(1951) .-24)$ 前

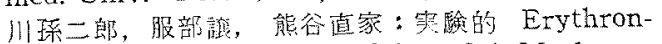
Allergy, 日血誌，13，263(昭25). - 25) Maekawa, M.: "Erythron-Allergy", " Lymphon-Allergy", "Leukon-Allergy" and "PanhematonAllergy", Acta Sch. med. Univ. Kioto., 32, 196 (1954). - 26) Maekawa, M.: The Role of Cell Phosphatides in Tissue Specific Allergies, Int. Arch. Allergy, 6, 384 (1955). - 27)

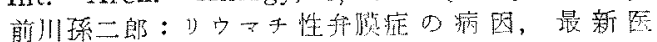
学, 10,2428(昭30)。一28) 前川孫二郎：白已

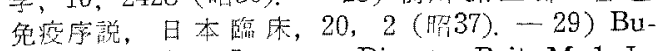
rnet, M.: Auto-Immune Disease, Brit. Med. J., Oct. 1) 645 \& Oct. 17, 650 (1959). - 30) Kaplan, M.H. et al.: Immunologic Relation of Streptococcal and Tissue Antigens, J. Immunol., 90, 565 (1963). - 31) Selye, H.: Stress, Acta. INC., Montreal, 1950. - 32) Pickering, G.W.: High Blood Pressure. Grune \& Stratton, N.Y., 1955。 - - 33) 前川孫二郎：心身相関の法则々意義 及びをの模造炕ついて，精神身体医学， 3， 184 (1963). 